\title{
Internet of Things for Smart Future Science Laboratory in Middle School: A Literature Review
}

\author{
N F Kusuma ${ }^{1}$, J Ikhsan $^{2}$, A Hujatulatif ${ }^{1}, \mathrm{~K} \mathrm{Huda}^{1}$ \\ \{nurulfajriani.2019@student.uny.ac.id\}
}

Science Education Program, Postgraduate, Universitas Negeri Yogyakarta. Colombo Street No. 1, Karangmalang, Sleman, Yogyakarta ${ }^{1,3,4}$, Chemistry Education Program, Mathematics and Science Faculty, Universitas Negeri Yogyakarta. Colombo Street No. 1, Karangmalang, Sleman, Yogyakarta ${ }^{2}$.

\begin{abstract}
Technology is urgently needed in the era of education 4.0 when technology and human are straight to bring through the new odds of multimedia and technology. The 21 st century education in the digital literacy era requires students to able for using the multimedia technology. The recently of the new technology that are start to be widely is The Internet of Things (IoT). The technology concept that can expand using of internet connectivity by automatically connecting us to objects around us called IoT. IoT connecting us by censoring object. The IoT has commenced to broadly used and discussed in any fields such as education field, health field, architecture field, etc. Smart homes, smart cities, smart rooms, smart libraries, etc. also take advantage of IoT technology to facilitate their work. The reasearch using a literature review method. The aims of this paper is to see the benefits and the framework of IoT technology when it applied to a smart laboratory in middle school level.
\end{abstract}

Keywords: Internet of Things (IoT), Middle school, Science Laboratory, Smart Laboratory.

\section{Introduction}

Education 4.0 responds to what the Industry Revolution 4.0 needed when the technology and human are straight to bring through the recent odds of multimedia and technology. The teacher needs to learn and equip themselves with digital tools to meet Gen $\mathrm{Z}$ learners [10]. The 21 st century is the digital era's literacy, where educators must be able to use multimedia technology such as learning methods through animation from scientific skill and scientific concept [22]. Educational Technology and Mobile Learning say that educators can use many digital tools to make learning more enjoyable. There are so many technologies that can operate as learning media in this 4.0 era [7]. professional life to social relationships covered on the internet has changed drastically in our experience interactions that move among humans on a virtual level in several contexts. IoT has stuff to add a recent process of dimension by sustaining communication between smart goods, thus leading to a vision of communication "anywhere, any media, anything, anytime"[4].

Teachers are required continuously to a learning method that is more interactive and innovative. Learning breakthroughs combine audio, script, music, images, videos, or animated images to unity that bolster each other to achieve learning objectives that can create a sense of joy during the teaching and learning process. it can work up student motivation during the teaching and learning process so that maximum learning objectives obtained [18]. IoT is a 
technology that is currently growing in the current era of 4.0. IoT technology is developing global-based information. IoT is the recent model that is summarily increasing in the modern wireless telecommunications scenario. IoT basic concept is the spread of attendance around us in various things or objects - such as sensors, cell phones RFID tags, or actuators. IoT past a unique addressing scheme. It can cooperate with their neighbors and interact with each other to achieve common goals. [8]. IoT is the physical system objects that integrated seamlessly into IT networks, and the items can be active participants in business processes. The IT service is available to connect with this 'smart object' by the internet, and they're asking for the status and information related to it, taking into account security and privacy concerns. [3].

IoT can use to create an intelligent system. Smart city, smart room, smart library, etc. is an example of using IoT. In the education system, IoT has also widely used, one of that is the use of a smart classroom. One of the science facilities that must operate in middle school is a science laboratory. So far, the use of laboratories has mostly ignored. According to Rahman \& Sumenep (2017), teachers are reluctant to use laboratories because many laboratory facilities and infrastructure are damaged, this is due to lack of common control, and damaged equipment is immediately not handled.

Besides, according to Putu Subamia (2015), there are several obstacles faced by schools in implementing laboratory management, namely: limited space and laboratory facilities, limited laboratory tools and materials, unavailability of laboratory staff, there's no SOP for laboratory management, inability teachers manage to learn following the availability of sufficient time, psychological barriers for teachers who are not satisfied if they don't lecture much during learning, there is no guarantee of safety and health of laboratory workers, and limited operational support funds.

IoT can be a solution for teachers in controlling all student activities in the laboratory. Laboratory facilities and infrastructure can be maintained periodically, even remotely using IoT technology. In this paper, we will provide a solution to the use of IoT in making a smart science laboratory in middle school. The aims of this paper is to see the benefits and the framework of IoT technology when it applied to a smart laboratory in middle school level.

\section{Methods}

The methods of this paper using a literature review. This paper is began by collecting the articles from google scholar and some books which talked about the basic of the Internet of Things, the uses of IoT, benefit, and the ideal standard of laboratory in middle school. The keyword in google scholar is a Internet of things, Middle school, and science laboratory. This paper writing by read the disscusion part of the collecting articles and see the research paper of using IoT in many field.

\section{Results and Discussion}

\subsection{The Ideal Standard of Science Laboratory in Middle School}

Science laboratory has a direct effect on students' academic attitudes and performance according to the learning interaction theory. It generally believed that continuous practice leads to proficiency in what students learn during classroom teaching. The involvement of students in laboratory activities has shown a benefit on student achievement in the science field. In laboratory activities, students work on questions, problems, or hypotheses 
individually or in small groups. Laboratory activities are a way that sustain students to learn with concept and at the same time, be involved in the process of constructing learning by doing science. [13]

The science laboratory in middle school has National Standards regulated by Permendiknas No. 24 of 2007 in which the science laboratory functions as a place for science practice activities that require special equipment. The special equipment referred to is Science laboratory has a direct effect on students' academic attitudes and performance according to the learning interaction theory. It generally believed that continuous practice leads to proficiency in what students learn during classroom teaching. The involvement of students in laboratory activities has shown benefit on student achievement in the science field. the Science Tools, which is a set of props needed to carry out science experiments [5]. A good layout in the science laboratory at middle school level has: 1) entrance,2) exit,3) emergency door,4) preparation room,5) equipment room,6) task room,7) storage room,8) staff room,9) workroom,10) warehouse room, 11) glass cabinet,12) tool cabinet optics,13) doors, 14) windows, 15) fans,16) and air conditioners for specific devices that require air conditioning [14].

The use of science laboratory space and tools must also be considered safe and comfortable for educators and students. The excellent management of science laboratories, according to the Development of the Directorate of Middle Schools [14], has the following characteristics:

- Practical is equipment that supports the improvement of the quality of the learning process or practicum;

- $\quad$ Efficient is that the equipment setting does not waste energy and costs.

- Healthy and safe are lightings, ventilation, sanitation, clean water, work safety and the environment all meet the requirements.

- Equipment/facilities are always ready to use and safe, meaning that all equipment/facilities are protected from damage, congestion, and protect from loss

- All laboratory activities are easily controlled, namely with good administration, clear information visualization and straightforward programs

- Fulfilling psychological needs are visually attractive, pleasant, good working climate and adequate physical and mental well-being.

Some of the location selection issues that are important for the environmental aspects, safety and health of the laboratory building be made up of the following [6]:

- Capacity and availability of significant requirement at the location;

- $\quad$ Access to vehicles and services to location and in location;

- $\quad$ Security and safety facility;

- Circulation of walking people to the location and in location;

- Subsurface conditions affecting the building structure and drainage site;

- Landscape features and surrounding buildings that have and impact the quality of air; supply and the spread of waste of the laboratory building;

Contamination of water or soil on-site due to using laboratory previously.

\subsection{The Ideal Standard of Science Laboratory in Middle School}

Internet of Things (IoT) is a construct which aims to expand the use of internet connectivity widely, where we can connect with various objects that are around us. IoT is an IT revolution that presents the future of communication and multimedia, and its evolution 
requires a support of innovative technology. [21]. IoT reduces human interference by introducing a device to device. The application of IoT in a smart laboratory can be very beneficial. We can monitor the energy and control equipment in the laboratory. Total energy consumption can reduce by using the IoT system. Where, in a whole year energy use can reduce by $30 \%$ by using a smart laboratory system [15]. IoT technology removes the limitations of physical attendance and expands access to any educational resource such as teachers, any tools and anywhere that facilitates E-learning efficiently. The IoT promises a necessary effect on the learning process in higher education by offering students, and teachers access to global resources and possibilities [1].

As the recent network connects information from company assets, operating environment, or the products, IoT can improve data and analysis, that can significantly enhance decision making. Some association begin to apply the applications in the spot planned, while general and demandingly apply still in experimental or the conceptual stages [11].

IoT has classified into three areas; these are[2]:

- A human with human,

- Human with things

- $\quad$ Object with an object, communication via the internet

Recently, RFID is appeared as the essential IT for changing a wide level of applications, including supply anti-counterfeiting, retail, chain management, aircraft maintenance, healthcare and baggage handling. It also signs the appearance of an expand cheaply and highly useful computer that will have a dramatic impact on society,individuals, and organizations [19].

According to Weber \& Weber [24], there are various kinds of IoT techniques in connecting one object to another:

- RFID (Radio Frequency Identification)

RFID is the system that can use to track and find assets automatically via waves of wireless radio. In common, this system consists of two-part, namely a transponder as a carrier of information, and the reader, it is a registration device which is reading a transponder information.

- EPC (Electronic Product Code)

A unique number encoded on the RFID tag is called EPC. EPC made up of a header that assigns a type of EPC and how to read the other parts of the EPC. Usually, the EPC is in the form of a serial number.

- ONS (Object Naming Service)

A service that contains a service address where each available service contains EPC data is ONS. Apart from storing all data about RFID chip/tag, the transmission of data thru servers distributed the internet can achieve through cross-linking via the ONS. ONS can also work as a core for computing throughout, allowing intelligent surrounding to admit and classify objects and get data from the internet to aid their adaptive functionality.

- EPC Discovery Service

EPC Discovery Service is a system which looks for EPC related data, but it isn't like ONS. The EPC contains not only pointers for specifying the original EPC code, but also for any code.

- Graphic Overview 


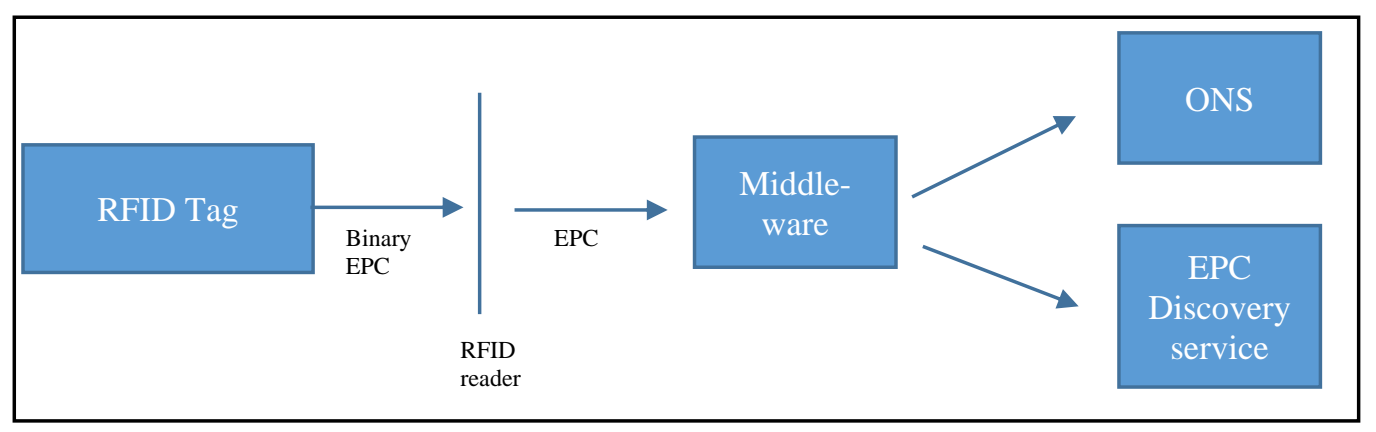

Fig. 1. IoT using RFID tagged object

RFID is a considered automatic identification method; it believed by general people to be unity about the rifest IT in history. RFID is the foundation on retrieval of data using devices and remote storage and called RFID chips/tags or RFID carriers. he technology of Automated identification, such as Auto-ID operations based on RFID technology, is crucial assets as record systems for two reasons. Firstly, the clarity provided by this technology recognizes accurate knowledge of index levels by reducing the difference between index records and physical record. Second, the RFID system can restrict or decrease the causes of error. The profits of applying RFID technology involve reduced workforce, simplification about business processes and reduced inventory inaccuracies [20].

Apart from RFID, WSN (Wireless Sensor Networks) also use as the necessary technology of IoT which adopts intelligent, interconnected sensors to monitor transmitting data to the central site where the data obtained does collect and can be further processed. The uses of WSN include disaster management, environmental and environment monitoring, health care applications, and battleground monitoring. Near Field Communication (NFC) is also frequently used recently, Bluetooth, universal mobile accessibility (hotspot, WiFi, cellular network), social networks and cloud computing, to support the IoT paradigm in infrastructure definition [9].

IoT system that mostly used in education are [2]:

- Digital smartboard

- interactive learning

- Educational applications for mobile and tablet devices

- E-books introduce the most helpful method to study

- Other training media such as Google Apps, which let learners and educators participate online

- Development of information

- Wireless door lock

- Study anytime and anyplace

- $\quad$ Take further measures of safety

- Heat sensor

- Participation tracking system

Third-party applications are various applications from wearable electronic devices that could grow the standard, including wearable sensor patches, augmented reality glasses and, smartwatches. It can extend significantly to use, comfortable to wear computing everywhere by the following link from data processing and transportation improvements, miniaturization 
tools, and new series technologies such as energy gathering through vibration, light, and heat [20].

\subsection{The Framework for Applying IoT in Smart Science Laboratory}

IoT has begun to be used in various fields, including in the field of education, from using IoT to create a smart classroom to a smart laboratory. The following is a figure 2 of IoT application that can use to create a smart science laboratory for middle school level.

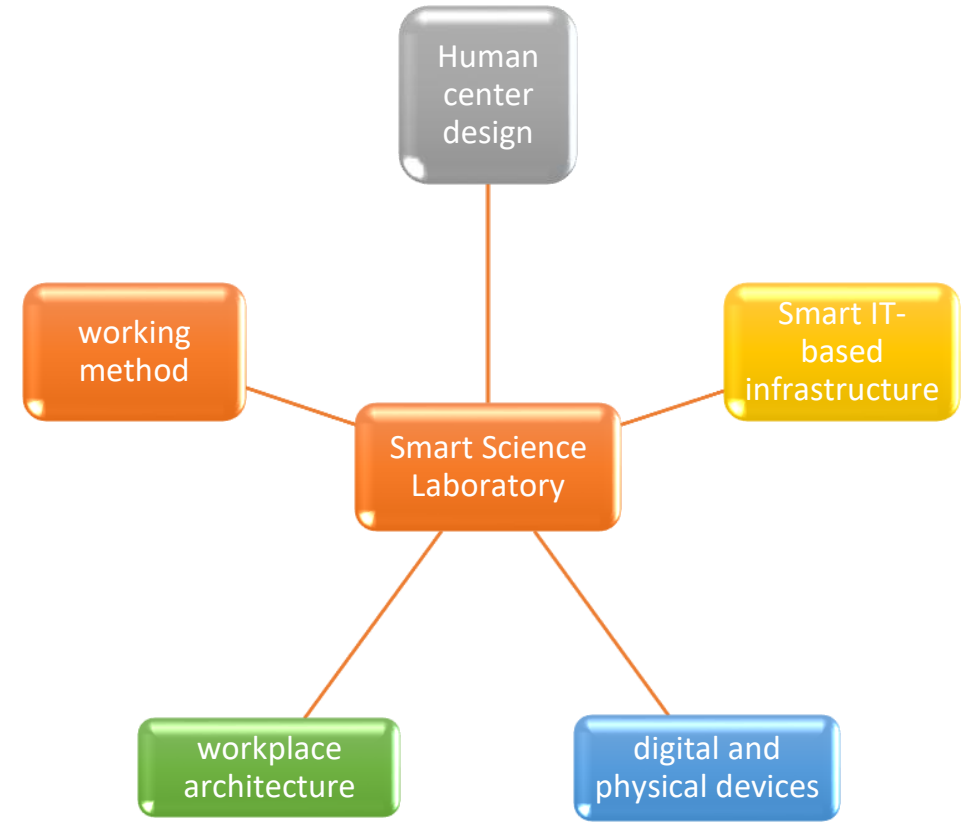

Fig 2. IoT utilization area in intelligent smart science laboratory

We must consider five key areas when utilizing IoT in an intelligent smart science laboratory in middle school level:

- Human-centred design: general analysis of the needs of the user, and the environment around them is the primary step for building an intelligent environment. It can make it practical for the teacher to control the development of the entire group of students while working in the lab at one time.

- Smart IT-based infrastructure: the foundation of intelligent learning is smart IT where wise IT is referred to as 'digital agents' and 'digital assistants'

- Digital and physical devices: every digital device (smart-device utilisation) with the device must intelligent combined with physical devices (smartpens, smart TVs, tablets, air conditioners, lamps, etc.)

- Workplace architecture: the architecture where students do all laboratory activities must pay attention to safety, cleanliness and occupational health.

- Method of work: a hybrid learning environment was created for the needs of students to work in a smart laboratory. Students' laboratory practice guides are available digitally so that they can easy monitored. 
Either the achievements of a smart city are to implement and protection to their residents with safe. For achieving the plan, an intelligent pressure system required that can utilize to law enforcement, crime detection, and accident and natural disaster management. To collecting the information, many instruments have been produced, such as CCTV (closed-circuit television) cameras and traffic sensors. This information, accompany by analytical evaluations, include possible improvements in the quality of data managed by fire departments, police departments and hospitals [23].

Meanwhile, to make a smart laboratory requires smart sensors and systems to:

- Facilitate the collection of laboratory administrative data;

- Control the storage area for tools and materials;

- Control the sterilization of instruments and materials;

- Control security;

- Control laboratory cleanliness.

The IoT platform is essentially a software product, offering a complete set of independent application functionalities which is using to build IoT applications. The structure of each IoT platform could be the difference as providers concentrate on various features of the IoT technology mound and thus include a diverse set of functions in their contributions. So, there is no arrangement standard of the IoT platform, but there are various IoT platforms, which address particular needs and application domains[25].

The drawbacks about using IoT to create a smart system are: First, because the IoT production is in the forward steps of evolution, may be its too early for a thorough review of this division. The specific way and impact of the IoT economy are unclear. How the market develops may be, in fact, very different from the way of advised by the popular stage of movement in the modern startup. Secondly, there are obstacles to the immediate and everywhere adoption of IoT products and services for various excuse. Sensors are still expensive; battery life remains an issue; information transmission is not a light issue. Location data is uncertain, wireless coverage is not throughout, and in most cases, significant information currents cannot interpret directly. It is not simple to change the information stream becomes important real-time [20]

\section{Conclusion}

Internet of Things is a constract that can use to create an intelligent system. This smart system can help us in everyday life; this smart system can also help us in shaping an IT-based learning education 4.0. The creation of an IoT-based smart science laboratory in middle school can facilitate the teacher to controlling of all student activities in the laboratory and periodically controlling the facilities and infrastructure of the science laboratory easily anytime and anywhere. The framework of IoT has five keys, there are: (1) Human centre design; (2) Smart IT-Based; (3)Digital and physical device; (4) Workplace architecture; and (5) Method of work. So, by applying the IoT system to make a smart science laboratory in middle school level, it can controlling all over the activity in laboratory and make the facility in the laboratory will safe, hygiene, effective and efficient to use.

\section{References}

[1] Abbasy, M. B., \& Quesada, E. V. (2017). Predictable Influence of IoT (Internet of Things) in the 
Higher Education. International Journal of Information and Education Technology, 7(12), 914920. https://doi.org/10.18178/ijiet.2017.7.12.995

[2] Abdel-Basset, M., Manogaran, G., Mohamed, M., \& Rushdy, E. (2019). Internet of things in smart education environment: Supportive framework in the decision-making process. Concurrency Computation, 31(10). https://doi.org/10.1002/cpe.4515

[3] AjazMoharkan, Z., Choudhury, T., Gupta, S. C., \& Raj, G. (2020). Internet of things and its applications: An overview. Lecture Notes in Electrical Engineering, 643, 67-75. https://doi.org/10.1007/978-981-15-3125-5_8

[4] Atzori, L., Iera, A., \& Morabito, G. (2010). The Internet of Things: A survey. Computer Networks, 54(15), 2787-2805. https://doi.org/10.1016/j.comnet.2010.05.010

[5] BSNP. (2007). Peraturan Menteri Pendidikan Nasional RI No.24 Tahun 2007. Bsnp.

[6] DIBERARDINIS, L. J., BAUM, J. S., FIRST, M. W., GATWOOD, G. T., \& SETH, A. K. (2013). Guidlines For Laboratory Design: Health, Safety, and Environmental Considerations Fourth Edition (4th ed.). John Wiley \& Sons, Inc. https://doi.org/10.1002/9781118633816

[7] Educatorstechnology. (2016). 4 Education Web Tools to Create Interactive Lessons. Retrieved from Educational Technology and Mobile Learning: https://www.educatorstechnology.com

[8] Giusto, D., Iera, A., Morabito, G., \& Atzori, L. (2010). The Internet of Things: 20th Tyrrhenian Workshop on Digital Communications. In Springer. Springer. https://doi.org/10.1007/978-1-44191674-7

[9] He, J. S., Ji, S., \& Bobbie, P. (2017). Internet of things (IoT)-based learning framework to facilitate STEM undergraduate education. Proceedings of the SouthEast Conference, ACMSE 2017, 88-94. https://doi.org/10.1145/3077286.3077321

[10] Hussin, A. A. (2018). Education 4.0 Made Simple: Ideas For Teaching . International Journal of Education \& Literacy Studies, 92.98.

[11] Iera, A., Floerkemeier, C., Mitsugi, J., \& Morabito, G. (2010). The Internet of things. IEEE Wireless Communications, 17(6), 8-9. https://doi.org/10.1109/MWC.2010.5675772

[12] Miller, J. D. (2002). The BW Protocol as a Health Care Intervention Arms Control : Where Now? Journal of the Federation of American Scientists, 55(1), 3-5. https://fas.org/faspir/2002/v55n1/v55n1.pdf

[13] Pareek, R. B. (2019). An assessment of Availability and Utilization of Laboratory facilities for Teaching Science at Secondary Level. Science Education International, 30(1), 75-81. https://doi.org/10.33828/sei.v30.i1.9

[14] Pembinaan Direktorat Sekolah Menengah. (2017). Panduan pengelolaan dan pemanfaatan laboratorium ipa.

[15] Poongothai, M., Subramanian, P. M., \& Rajeswari, A. (2018). Design and implementation of IoT based smart laboratory. 2018 5th International Conference on Industrial Engineering and Applications, ICIEA 2018, April 2020, 169-173. https://doi.org/10.1109/IEA.2018.8387090

[16] Putu Subamia, I. D. (2015). Analisis Kebutuhan Tata Kelola Tata Laksana Laboratorium IPA SMP di Kabupaten Buleleng. JPI (Jurnal Pendidikan Indonesia), 3(2), 446-459. https://doi.org/10.23887/jpi-undiksha.v3i2.4461

[17] Rahman, M. S., \& Sumenep, S. (2017). Kajian Standarisasi Sarana Prasarana Laboratorium Di Smpn 4 Sumenep. Jurnal Lensa (Lentera Sains): Jurnal Pendidikan IPA, 7(24), 1-12.

[18] Sapurta, W., \& Purnama, B. E. (2012). Pengembangan Multimedia Pembelajaran Interaktif Untuk Mata Kuliah Organisasi komputer. journal Speed-Sentra Penelitian Engineering dan Edukasi, 4. Retrieved from ijns.org

[19] Sun, C. (2012). Application of RFID Technology for Logistics on Internet of Things. AASRI Procedia, 1, 106-111. https://doi.org/10.1016/j.aasri.2012.06.019 
[20] Swan, M. (2012). Sensor mania! the internet of things, wearable computing, objective metrics, and the quantified self 2.0. Journal of Sensor and Actuator Networks, 1(3), 217-253. https://doi.org/10.3390/jsan1030217

[21] Tan, L., \& Wang, N. (2010). Future Internet: The Internet of Things. ICACTE 2010 - $20103 r d$ International Conference on Advanced Computer Theory and Engineering, Proceedings, 5, 376380. https://doi.org/10.1109/ICACTE.2010.5579543

[22] Turiman, P., Omar, J., Daud, A. M., \& Osman, K. (2012). Fostering the 21st Century Skills through Scientific Literacy and Science Process Skills. Procedia - Social and Behavioral Sciences, 59, 110 116. https://doi.org/10.1016/j.sbspro.2012.09.253

[23] Ud Din, I., Guizani, M., Hassan, S., Kim, B. S., Khurram Khan, M., Atiquzzaman, M., \& Ahmed, S. H. (2019). The Internet of Things: A Review of Enabled Technologies and Future Challenges. IEEE Access, 7, 7606-7640. https://doi.org/10.1109/ACCESS.2018.2886601

[24] Weber, R. H., \& Weber, R. (2010). Internet of Things. In Cyber Resilience of Systems and Networks (Issue July 2016). https://doi.org/10.1007/978-3-319-77492-3_16

[25] Wortmann, F., \& Flüchter, K. (2015). Internet of Things: Technology and Value Added. Business and Information Systems Engineering, 57(3), 221-224. https://doi.org/10.1007/s12599-015-0383-3 